\title{
Typography and nationalism: the past and modernism under Nazi rule
}

Article

Accepted Version

Waldeck Villas Boas, M. (2020) Typography and nationalism: the past and modernism under Nazi rule. Journal of Visual Political Communication, 6 (1). pp. 37-80. ISSN 2633-3740 doi: https://doi.org/10.1386/jvpc_00003_1 Available at https://centaur.reading.ac.uk/91676/

It is advisable to refer to the publisher's version if you intend to cite from the work. See Guidance on citing.

To link to this article DOI: http://dx.doi.org/10.1386/jvpc_00003_1

Publisher: Intellect

All outputs in CentAUR are protected by Intellectual Property Rights law, including copyright law. Copyright and IPR is retained by the creators or other copyright holders. Terms and conditions for use of this material are defined in the End User Agreement.

\section{www.reading.ac.uk/centaur}

\section{CentAUR}

Central Archive at the University of Reading

Reading's research outputs online 


\title{
Typography and nationalism:
}

\section{The Past and modernism under Nazi rule}

Mila Waldeck

University of Reading

\begin{abstract}
In 1941, the Nazi regime revoked the long-established convention of typesetting German texts in Fraktur styles. ${ }^{1}$ This study examines the significance of the messages conveyed by letterforms in Nazi propaganda and the extent to which the regime put into practice its professed typographic policies. Taking into account different audiences and channels, it focuses on books by the Ahnenerbe institute controlled by Heinrich Himmler, the women's magazine NS-Frauen-Warte and the newspaper Völkischer Beobachter. Fraktur styles seem to have functioned as the main letterforms of the blood and soil ideology, but another strand of Nazi typography departed from Fraktur and probably translated the importance of the Oera Linda book and the Codex Aesinas in the image of a supposedly 'Aryan' past. Meanwhile, the Nazi propaganda incorporated forms and norms that it appropriated from modernist typography, a topic implicitly raised in the dispute between Max Bill and Jan Tschichold in 1946. Typography functioned as instrument for exclusion, racial discrimination and gender stereotyping and to mark the boundaries of the 'Aryan' community, challenging the notion of print-language as intrinsically inclusive expressed in Benedict Anderson's Imagined Communities.
\end{abstract}

\section{Keywords}

Ahnenerbe; NS-Frauen-Warte; Völkischer Beobachter; Jan Tschichold; Max Bill; nationalism; Nazi propaganda; Imagined Communities

1.Peter Bain and Paul Shaw used the word 'Blackletter' as an umbrella for letterforms commonly used in Germany in the past, such as 'Textura' and 'Rotunda', but Bain (1998: 71) stated that 'Fraktur' is another possible term. The second alternative is used here. For a description of different styles of Fraktur, see Bain and Shaw's (1998). 
Nazi propaganda notoriously put Fraktur typefaces in service of a national image. So it may seem contradictory that the Nazi regime decided to extinguish the very letters that it employed to distinguish 'German' from 'non-German'. This study looks into this possible contradiction. Divided into five parts, the text initially overviews the visual representation of German language across bi- and multilingual dictionaries from the sixteenth to the twentieth centuries. They indicate that Fraktur letters gradually became a German script often unfamiliar to international readers; thus, the Nazi-imposed change of script in 1941 likely seemed at the time a practical imperative for Germany's territorial expansion. The subsequent parts deal with symbolic uses of letterforms in different contexts, where they functioned to evoke the past and represent modernity and to disseminate racism and gender stereotypes. The second part focuses on books from the Ahnenerbe institute, linked to the male-only SS (Schutzstaffel), while the third one focuses on the women's magazine NS-Frauen-Warte. The influence of modernist typography in the Nazi design, of which the newspaper Völkischer Beobachter is an example, is discussed in the fourth part. In the fifth and final part, these nationalist typographies are readdressed alongside the concept of print-language from Benedict Anderson's theory of nationalism.

Primary sources included microfilm reproductions of the Völkischer Beobachter (period covered: 1920-45) as well as books from the Ahnenerbe institute (period covered: 1936-43), all from the British Library. The Ahnenerbe magazine Germanien was not included in this study. NS-Frauen-Warte was accessed in Online collections from the Heidelberg University Library and Biblioteka Elbląska (period covered: 1932-45). Additional sources were ephemera and Nazi reports from digital collections of the Holocaust Memorial Museum and Hoover Institution at Stanford University, as well as the Reich's stationary and stamps documented in the Nuremberg Trials Project at the Harvard Law School Library (photostat copies) and available on the CIA website (photographic copies).

\section{Mother tongue and fatherland}

For almost five hundred years, German texts were shaped by typefaces that increasingly became a visual signature. The contrast between German, commonly printed in Fraktur, and languages in Roman letters looked evident irrespective of the reader's familiarity with the language itself. Such a long-established and national-distinguishing tradition would not sound like something that the Nazi regime would extinguish. Under Nazi rule a literature with linguistics pretenses had been stating that language and race were indissociable and the pure German language was 
inaccessible to 'non-Aryans' (Kämper-Jensen 1993: 173-76). This claim preceded the Nazi party and had been expanded by nationalist associations formed around Fraktur, allegedly the only authentically German letterform (Ulbricht 2004: 78-79). Elsewhere, Fraktur had become a display font, used for example in newspaper mastheads but rare for continuous reading.

In early January 1941, a circular 'on behalf of the Führer' declared that it was false to call Fraktur letters the German typeface: In reality they were 'Jewish letters' that should be replaced by 'normal' (Roman) ones (Willberg 1998: 48). The circular opened a series irrevocable antiFraktur measures, including the prohibition on producing it (Ruck 1993: 259). This seems to contradict the prompt anti-modernist actions of the Nazi regime such as sealing off the Bauhaus in April 1933, but as Rück (1993), Margolin (2015) and Evans (2004) observed, Nazism appropriated and cancelled both the past and the modern.

How randomly did it use and destroy the old and the new? The anti-Fraktur directive was synchronized with Hitler's order to invade the Soviet Russia. It postponed the change in schoolbooks but speeded it in 'newspapers and magazines that already have foreign circulation or whose foreign circulation is desired' - so that while the troops advanced, a Nazi news narrative also spread. Right in the beginning, the circular attacked the news industry, allegedly always owned by the Jews who thus disseminated Jewish typefaces. It was implied that the change to 'normal' writing, as the circular called it, was part of a process of clearing the news themselves of the 'abnormal' Jewish presence. Implicitly non-Roman scripts in general were defined as abnormal too.

Bilingual and multilingual dictionaries show that the notion that Fraktur was the German alphabet, so ingrained that it was cancelled by decree and had not always been self-evident. In the Latin-German dictionary, Vocabularius optimus printed by Melchior Lotter in 1501 in Leipzig the two languages flow undifferentiated, both in Fraktur (Figure 1). In Nicolao Volkmaro's Latin-German-Polish dictionary printed by Iaccobi Rhodi in 1596 in Dantisci (Danzig) German and Polish are both in Fraktur while Latin is in italic.

From the sixteenth century onward, dictionaries show Roman typefaces gradually spreading across other languages while German continued in Fraktur. In the multilingual, Thesaurus Polyglottus by Hieronymus Megiser printed in 1603 in Frankfurt am Main, Polish is in italic while German is in Fraktur (Figure 2). Increasingly, the typographic style functioned as a German-specific alphabet like cyrillic is the Russian one. Indeed, readers unfamiliar with German apparently needed Fraktur to be translated: The multilingual Universal European Dictionary of Merchandise printed in 1799 for J. Johnson in London romanized German and Russian (Figure 3). The Soldier's Pocket-dictionary, or Friend in Need printed by R. Hindmarsh 
in London in 1794 also romanized German, as did the Dictionnaire universel pour la traduction des menus en français, allemand et anglais published by the Art. institut Orell Füssli in Zürich in 1911.

Despite this German-specific semblance, Danish for example was typeset in Fraktur well through the nineteenth century, though inconsistently. In multilingual dictionaries published in Copenhagen in the early twentieth century, Danish was printed in different styles, but Roman seems to have become standard earlier for continuous reading: The first edition of Søren Kierkegaard's Forord. Morskabslasning for enkelte Stander efter Tid og Lejlighed (Prefaces. Light Reading for the Different Classes at their Time and Leisure), published in 1844 in Copenhagen by C.A. Reitzel is in Roman, as is Kierkegaard's Collected Works published by Gyldendalske Boghandels Forlag in 1901.

Such an enduring convention of Fraktur for German amid its international disuse suggest a distinction between German as seen from inside the communities of native speakers and the German read outside them. Hence, Peter Rück's (1993: 238) claims that scientific publications in German for the international market tended to be in Roman. More detachable from Fraktur than Russian was from Cyrillic, German texts moved from one typographic style to another, seemingly according to the readers' mother tongue.

A petition demanding that the first literacy classes across Germany be in Roman letters, voted in 1911, made clear the status of Fraktur as an alphabet and not merely a typographic style. On 17 October the Reichstag voted by 75 per cent to maintain Fraktur as the official script (Weiss 2017: 43). The shape of letters was thus a legislative matter, and the change set in motion in 1941 probably was not immediately felt as a new law because, unlike the 1911 rejected proposal, schools were not the first target of romanization.

German-language newspapers were often in Fraktur not only nationally but also internationally in the early twentieth century - the Kronen Zeitung from Vienna, Neue Zürcher Zeitung from Zürich and Deutsche Correspondent from Baltimore (Figure 4) are some examples. Thus, Fraktur encircled a speech community in a visual manner in addition to the verbal one and, conversely, for non-speakers the typeface was a further sign of something impassable. Linguistic and national boundaries did not necessarily coincide: The frontiers of the mother tongue, further heightened by typography, were not those of the fatherland.

\section{Design for crime}


The 1941 anti-Fraktur directive was rapidly followed by the Ahnenerbe (Ancestral Heritage Society), an organization founded on 1 July 1935 under the command of SS leader Heinrich Himmler. An undated mission statement declared:

The Research and Instructions group, 'Das Ahnenerbe', is charged with research into the capacity, spirit, accomplishments and heritage of the northern racial Indogermanism, vivifying the results and transmitting them to the public.

TASKS

Furnishing of teaching and research establishments

Assignment of research work and accomplishment of research trips

Publication of scientific promulgations

Further scientific work

Arrange scientific conferences

(Ahnenerbe n.d.)

'Research' and 'science', repeatedly emphasized, should conform to the belief in a racial spirit whose evidence were indisputable but yet to be shown. Initially, the organization's president was Dutch author Herman Wirth and the statement, though written when he was no longer presiding it, maintained his doctrine of a 'Nordic-Aryan race' of common cultural lineage. Wirth claimed that the 'Nordic-Aryans' emerged in the North pole, settled in Atlantis but it sunk, then they headed to other continents spreading their highly advanced 'Aryan' culture, and to substantiate this theory, as Horst Junginger (2008) wrote, Wirth 'pressed heterogeneous things together if they seemed to fit into his system by their outward appearance' (2008: 115).

Wirth asserted that the well-developed writing system that the 'Aryans' invented in Atlantis originated all others, though in an inferior form due to other people's inferior race. Supposedly, this pioneering script resembled pseudo runes, which Wirth scattered throughout his book Der Aufgang der Menschheit ('The Dawn of Mankind') published in 1928. The rune-mimicking Ahnenerbe imprint and SS insignia resonates such ideas (Figures 5-7).

He also used runic forms to illustrate his edition of Die Ura Linda Chronik, a hoax that tells the origin of a formidably ancient 'Aryan' race, which Wirth translated to German and presented as trustworthy in a 1933 edition. The original edition, Thet Oera Linda Bok, naar een handschrift uit de dertiende eeuw (The Oera Linda Book From a Manuscript of the Thirteenth Century) published in 1872 in the Dutch city of Leeuwarden, is illustrated by two 'facsimile' pages from the original 'manuscript of the thirteenth century', written in rune-styled letters (Figure 8). In his own version, Wirth rendered the fake story more persuasive by adding photographs.

Ahnenerbe editions switched to Roman in 1941, though already in 1939 the book Axt und Kreuz bei den Nordgermanen ('Ax and cross by the Nordic Germanic people') was published in a Didone style. Except for the paperback, Was Wird Mit Frankreich? ('What will happen to France?') by Wilhelm Ziegler, copies of Ahnenerbe books look like something between the 
ordinary book and the luxury edition. The margins are wide and the smooth-textured paper is also heavy-weighted and hard-covered as if costs and material were not a problem. The dark and even printing indicates that the ink was plentiful. Photographs abounded and were well reproduced in coated paper, and a coffee-table book size of approximately $21 \times 28.5 \mathrm{~cm}$, the same size of Wirth's Der Aufgang der Menschheit, was standard though not a rule. The insertion of non-Roman characters within the text, common to Wirth's editions, was also an Ahnenerbe practice (Figures 9-10).

As WW2 advanced, 1943 editions were sometimes in cheaper paper stock but their large size and well-printed images still look ostentatious considering the context. Particularly dissipative of time, supplies and money is the $22 \times 28.5 \mathrm{~cm}$ firmly bound Handschriftliche Untersuchungen $z u$ Tacitus Agricola und Germania. Mit einer Photokopie des Codex Aesinas, a study about Tacitus' Agricola and Germania containing a 108-page text by Rudolf Till printed on thick uncoated paper, as well as a facsimile of the fifteenth century Codex Aesinas reproduced on 58 coated pages. Dated to around $98 \mathrm{CE}$, Germania supposedly confirmed that a German race evolved unmixed and that its supremacy was a historically proven fact. Significantly, the Codex Aesinas, considered the oldest extant manuscript copy of Germania, is handwritten in Roman style, not in Fraktur (Figure 11). It bestowed an aura of legitimacy on Nazism, and the publication of this Ahnenerbe edition in 1943 amid defeats of German troops tells how important such aura was, especially considering that an order in given July 1942 had pressed the Ahnenerbe to conduct military research.

Hellmut Lehmann-Haupt ([1954] 1973: 144) observed that librarians of the Library of Congress and New York Public Library diligently catalogued numerous books brought to the United States after the war with an innocuous imprint Ahnenerbe, without noticing that they were published by Heinrich Himmler's atrocious SS. 'This failure was exactly what Heinrich Himmler and Wolfram Sievers, the minister of culture in Himmler's personal SS empire, have intended' (Lehmann-Haupt [1954] 1973: 144). The Ahnenerbe mission implied Wirth's method where the certainty precedes the evidence, yet under an enhanced apparatus of scientific research. The book design further portrayed violence as neutrality.

Before joining the Ahnenerbe in 1935, Wolfram Sievers worked for Wirth and then for the publishing company Bruckmann, owned by avid backers of Hitler. Via Bruckmann he met Walther Wüst, professor in the 'Department of Aryan Culture and Linguistics' in the University of Munich and Rector of the same university from 1941 to 1945 (Kater 2006: 33, 43). In the Ahnenerbe official hierarchy, Sievers and Wüst became second to Himmler. 
It was Bruckmann that published what Ritchie Robertson (2001: 171) called 'one of the few books read by many leading Nazis' including Hitler, Goebbels and Himmler: The anti-Semitic bestseller Die Grundlagen des neunzehnten Jahrhunderts (The Foundations of the Nineteenth Century), first issued in 1899, by English Germanophile Houston Stewart Chamberlain. Goebbels' novel Michael, Robertson (2001: 171) noted, repeated Chamberlain's claim that Jesus was not Jew - surely, he was 'Aryan'.

Justified as research into the 'heritage of the northern racial' the Ahnenerbe organized 'looting of cultural objects on a grandiose scale', as Lehmann-Haupt ([1954] 1973: 155) described it, synchronized with Nazi invasions. On another front, Francisco Gracia Alonso (2008) demonstrated that Franco's regime in Spain subsidized excavations in Segovia in 1941 led by Julio Martínez Santa Olalla and pre-coordinated with the Ahnenerbe. At Himmler's request, a publication about the expedition was initiated by Joachim Werner, professor from Tübingen University and Inspector General of the Belgian Museums. The archeological material was then delivered to the Ahnenerbe and has remained in Germany (Gracia Alonso 2008: 11).

What especially interested the organization 'until almost the end of the war' were excavations in Canary Islands as they related to the presumed 'Aryan' civilization in Atlantis (Gracia Alonso 2008: 23). Such interest indicates how lastingly the Ahnenerbe took seriously ideas such as those contained in the Oera Linda book, a text of religious significance for Himmler, as Franz Winter (2016) pointed out. The forged antiquity of the rune-styled script surrounded of mystic aura the 'original manuscript', and supposedly debunked existing histories of the writing systems (Winter 2016: 25-26).

Fraktur, omnipresent in Germans' everyday life, bridged their language and the very history of the Jewish people via the Gutenberg and Luther Bibles, both printed in Fraktur styles. For the Ahnererbe, race and culture were absolutely the same thing, thus the 'Jewish race' would only be completely exterminated if its culture and religion, which outlives those that practice them, were extinguished too. Hence, the fabrication of another ancestry and heritage to replace the old one. Membership in the SS was compulsory for Ahnenerbe members and the position of the organization under the SS and under the command of holocaust implementer Himmler underscored the link between its research on 'ancestral heritage' and genocide. According to Michael Kater (2006), the organization at least initially aimed to occupy the ideological world of the SS members, considered the elite of the supreme race, thus Ahnenerbe books were possibly intended for them.

In the Nuremberg Military Tribunals 'Ahnenerbe' was an often-mentioned name - the transcript of case number one alone mentions it on 315 pages. Before quoting a report that 
Ahnenerbe manager Wofram Sievers submitted to Heinrich Himmler in February 1942, chief prosecutor Telford Taylor prepared the audience for the horror that would follow: 'These are perhaps the most utterly repulsive charges in the entire Indictment' (HLSL [1946-47] 2016: 43).

\section{Siever's text stated:}

We have a nearly complete collection of skulls of all races and peoples at our disposal. Of the Jewish race, however, only very few specimens of skulls are available with the result that it is impossible to arrive at precise conclusions from examining them. The war in the East now presents us with the opportunity to overcome this deficiency. By procuring the skulls of the Jewish-Bolshevik Commissars, who represent the prototype of the repulsive, but characteristic subhuman, we have the chance now to obtain a palpable, scientific document.

The best, practical method for obtaining and collecting this skull material could be handled by directing the Wehrmacht to turn over alive all captured Jewish-Bolshevik Commissars to the Field Police.

$[\ldots]$

Following the subsequently induced death of the Jew, whose head should not be damaged, the delegate will separate the head from the body and will forward it to its proper point of destination.

The horrifying 'palpable, scientific document' was conceived by August Hirt, director of the anatomical institute at the Reich University in Strasbourg. The Museum of Natural History in Vienna had a similar 'collection' (Lang 2013: 375), as well as skulls and death masks from concentration camps victims, and its department of anthropology issued racial certificates that could mean death sentences (Berner 2017: 122). In 1939, it opened an exhibition advertised as a neutral, scientific proof that the Jews and German should be separated due to their genetic differences (Heim 2019: 756).

The Ahnererbe tried to fabricate a past confined to this world-view and pre-fabricate the upcoming historical records. Hirt's collection would be a prospective data about extinguished

races. Past and future would thus be imprisoned into the perpetual supremacy of the 'Aryan race' from which there would be no escape because there would be no historical, cultural and religious references of any other possible life. Fraktur, chosen by Gutenberg and Luther to stamp the Old Testament, was one of such references.

\section{Typography for the national community}

In 1918, all German women over 20 years old were granted the right to vote and altogether they became the majority of the electorate. In the following year's election, women occupied 9.6 per cent of the National Assembly: Germany surpassed any other country in female political representation (Sneeringer 2002: 10). Consistently, the Nazi party lacked women's support, a pattern probably reversed in the 1932 elections despite its persistent unsuccess among working 
class and catholic women (Childers 1983). During the expansion of Hitler's powers in 1933, the party organized an exhibition to 'show the significance of the woman for the family, the people, and the whole nation' as Joseph Goebbels (18 March 1933) declared in the opening speech:

Looking back over the past years of Germany's decline, we come to the frightening, nearly terrifying, conclusion that the less German men were willing to act as men in public life, the more women succumbed to the temptation to fill the role of the man. The feminization of men always leads to the masculinization of women.

'Terrifying' was women holding public office and people's challenge to the Nazi stereotype of man and woman, yet Goebbels defined the stereotype with contradictory words that could sound reassuring for different listeners. In one passage, he conceded that he would sound 'reactionary' but ' $[T]$ he best place for the woman to serve her people is in her marriage, in the family, in motherhood'. Then, he swapped reactionary for new: 'This is the beginning of a new German womanhood'. Then, he restated that '[T]he national revolutionary government is everything but reactionary', subsequently saying the opposite: '[T]he national revolutionary government has the duty to rebuilt the nation on its original foundations'. These contradictions addressed clashing opinions about modern life and traditions. Undoubtedly, women were being ordered to have many children, be housewives and stay away from politics, but he presented this idea as something new and packed exclusion from public life as 'highest mission'.

Already in July 1932, the party launched the biweekly women's magazine NS-Frauen-Warte with a similar platform. In 1931-33, it was overseen by Elsbeth Zander, head of the women's league of the Nazi party (NS-Frauenschaft), then by Lydia Gottschewski in 1933-34. In 1934, Hitler appointed Gertrud Scholtz-Klink as head of Nazi Women's Bureau, whose eleven-year tenure included leading the NS-Frauenschaft and NS-Frauen-Warte, and visiting concentration camps (Hertrampf 2009). Underscoring the women's disenfranchisement, in January 1934 the magazine's slogan changed from 'magazine of the NS-Frauenschaft' to 'the only partyauthorized women's magazine'.

In NS-Frauen-Warte, the era of Roman letters never fully materialized: the body text remained in Fraktur until the last issue, dated 1944-45 and probably published in early 1945. This permanence was more likely deliberate than caused by technical constraints since the antiFraktur directive had prioritized the change of script in 'newspapers and magazines that already have foreign circulation'. In other words, the priority was to ensure the rapid dissemination of certain messages across certain audiences, not the practical difficulties in quickly supplying new type in great quantities. The only edition of NS-Frauen-Warte totally in Roman in January 1944 seems like a blunder fixed in the next issue. Titles in cursive styles were introduced in January 
1938, initially in the fashion section but gradually in other pages too (Figure 12), sometimes in the Sütterlin handwriting used in Germany. Similarly, cursives were used by NS-Frauen-Warte advertisers such as Nivea and Nestlé.

Italicized and human-evoking letterforms were also used in Nazi propaganda that targeted women and children and/or that promoted euthanasia. Institutions that handled the mechanics of the euthanasia program which, according to the records, killed 275,000 children and adults, sounded innocent with righteous names like 'Realm's Work Committee of Institutions for Cure and Care' and 'Charitable Foundation for Institutional Care', as Leo Alexander (1949: 39-40) argued. Handwriting and italics were their counterpart in the technique of painting horror with pastel colours, a palette literally used in eugenics and euthanasia campaigns, where Fraktur commonly addressed and represented a 'well-fit Aryan community' (Figures 13-14).

The prolonged survival of Fraktur in NS-Frauen-Warte and its rapid extinction in the Ahnenerbe indicate how the Nazi propaganda metamorphized according to the audience and situation. Fraktur embodied the pure 'Aryan' genes whose multiplication was the main duty of 'Aryan' women, marking who was foreigner and who belonged to the national racial community. Such conversion of Fraktur from typefaces for German texts into the typefaces of the 'Aryan race' is made clear in a poster about the Nuremberg Laws: to explain the prohibition of marriage and sex between 'Aryans' and 'non-Aryans' an illustration mapped Germany with texts in Fraktur within the national borders and in Grotesk towards bordering countries. When the presumed reader was from the German national racial community, the letter was Fraktur. Foreigners were addressed in Roman (Figure 15).

Thus, a typographic style common for German language was re-appropriated to mark race and national frontiers as the Nuremberg laws defined German as 'Aryan'. Conversely, everybody else was foreign therefore excluded. Nazism stretched the meaning of Fraktur by lumping together language, nationality, religion, political view, sexual preferences, gender identity, beliefs, culture, 'race'... By conflating different things into the label 'foreign', it could manipulate the shape of letters to demarcate the separation between the national 'Aryan' community and outsiders.

Despite the concreteness of Nazi violence, NS-Frauen-Warte fabricated an idyllic world of hills, trees, rivers, flowers, sunshine and birds. It functioned as an official channel for the blood and soil ideology that Richard Walther Darré promoted and implemented, of which Fraktur became the typographic voice. Elizabeth Harvey (2003: 141) pointed out that an article published in 1940 described flowers blooming and the 'splendid view' of a new home for German elderly persons in Poland, while in fact the place was originally a Polish psychiatric hospital with 700 
patients and most were probably killed. Given the systematic policy of euthanasia the 'new home' was likely a lie too. The magazine's version looks credible thanks to the photographs, while subheads in a Fraktur-styled handwriting humanized the story and claimed German ownership of the region (Figure 16).

The main redesign of NS-Frauen-Warte, in February 1938, was probably timed considering the annexation of Austria, legitimized in March-April 1938. Of greatest impact was the new cover, which changed from small monotone image to full-colour and full-page illustration. In April 1938, a map of the new German empire on red background fully filled the cover, followed in May by a landscape typical of the 'blood and soil' genre (Figure 17). In September 1939, the beginning of Second World War was announced with a cheerful sunflower on the cover and a three-page article about soldiers going to the war, portrayed singing and playing accordion. From then on war-related covers intercalated and increasingly surpassed the bucolic ones. In 1942, the magazine's frequency decreased. Still, in the NS-Frauen-Warte world the war was giving people land and housing. Even in 1944, when the reality of loss and destruction was so undeniable that the magazine published an article teaching how to build an outdoor fireplace and use it to cook and heat water, the title was in a flourished script that resembles wedding invitations (Figure 18).

The magazine's human-evoking handletters accompanied by countryside images diverted from the reality of the Nazi mechanical use of women as copy-machines to produce citizens for prospective use in the war and to multiply the 'Aryan race'. NS-Frauen-Warte referred to the reader's children as 'our children' - rather than 'your' - underlining that they belonged to the regime. The Nazi rhetorical glorification of the family clashed with its actual practice. Generally, there is no father in NS-Frauen-Warte: Women raised children, managed the house and did the farm work alone.

Yet, the magazine staged a world fractured into two parts: the main one in the initial pages exhibit a blood and soil repertoire of peasants and rural landscapes; the secondary part in the back pages tells stories about factory workers, nurses, librarians and schoolteachers, followed by a fashion section incompatible with the countryside life of the front pages (Figure 19). As the war continued, the secondary world advanced over the primary one. NS-Frauen-Warte chiefly tried to indoctrinate about the blood and soil myth while implicitly documenting how unattainable the myth was.

Its repetitive denigration of 'non-Aryan' men implies that German women were unconvinced. The regime forced millions of foreigners to work in Germany: in 1942, they were over 4.6 million, of whom 1.3 million were Poles. In some places, there were twice as many foreigners than German males (Ulrich 2015). In 1942, NS-Frauen-Warte published an eroticized 
photograph of a man - something uncommon in the magazine - captioned as 'German worker'

(Figure 20). The text campaigned against the contamination of the race with un-German blood, particularly Polish blood, which suggests that the regime was unable to fully control what happened to the 'Aryan genes'. Given the article's insistence on how nicely foreign workers lived, the horror of forced labour was probably known (or suspected) and backfiring.

Goebbels (18 March 1933) assured that employed women were accepted in 'the motherhood of the German people' but warned that women's 'real task', their 'mission', was 'in the family and as a mother'. In practice, as Rupp (1977: 375) stated, this was tailored 'for upper- or middleclass housewives. Working-class women may have detested their jobs, but they could not forsake them, and the Nazi glorification of woman as mother and housewife could do little for them'. Besides, the regime did need women working in areas other than the 'real mission', especially during wartime.

The pre-existing notion that language was a racial attribute set the scene for the Nazi racialization of letterforms - it was from the department of 'Aryan Culture and Linguistics' that Walther Wüst ascended politically. By same token, the German-specific Fraktur and Sütterlin scripts became genderized, since the dissemination of the 'Aryan race' was women's task.

\section{The industrialization of murder}

Nazism is not the antithesis of modernity, it is part of it - argued Horkheimer and Adorno in Dialectic of Enlightenment. 'Everything - including the individual human being, not to mention the animal - becomes a repeatable, replaceable process' in industrial society. 'Conflict between administrative, reifying science, between the public mind and the experience of the individual, is precluded' (Horkheimer and Adorno [1944] 2002: 65). From the darkness of such administration surfaced the language of Ahnenerbe manager Wolfram Sievers, where 'opportunity' to 'arrive at precise conclusions' through 'palpable, scientific document' signified mass murder. Sievers' wording and manner to systematize atrocities is a reminder of Horkheimer and Adorno's point.

It is disturbing that modernist typography was one of the facets of Nazi design, a facet obscured by the regime's aggressive appropriation of Fraktur. Modernism sounds further distant from any such link given the Nazi offensive against the Bauhaus in 1932-33 and arrest of modernist typographers Jan Tschichold and Paul Renner in early 1933. The dispute between Jan Tschichold and Max Bill in 1946 in the magazine Schweizer Graphische Mitteilungen stands as a remarkably frontal engagement with this difficult and relatively undiscussed topic. 
Bill triggered the dispute in the April issue with the article 'Über Typographie' (on typography), which attacked Tschichold for abandoning the modernism that he once defended in manifestos like The New Typography to practice 'Heimatstil' instead. The word was stained by blood and soil connotation - 'Heimat' was an often-used term in NS-Frauen-Warte (see Figures 12 and 16) - and unmistakably referred to the Nazi ideology. Such a loaded word expressed Bill's certainty that modernism and Nazism clashed in opposite fronts and probably incited Tschichold's pointed tone in his reply 'Glaube und Wirklichkeit' (Belief and Reality) in the June issue, which revived the Heimatstil accusation.

As Christopher Burke (2007: 303) observed, Tschichold's argument resembles the critique of modernity set forth in Dialectic of Enlightenment. Yet, Tschichold assigned to modernism specifically what Dialectic of Enlightenment argued about modernity more generally.

Unrestrained exaltation of progress and quest for absolute models characterize Nazism and modernism alike, he sated, hence his U-turn from campaigner to critic of modernism. Nevertheless, he gave no tangible examples of typographic intersections between Nazism and modernism.

The Nazi party' newspaper Völkischer Beobachter looks like one such example compared to other newspapers at the time. Founded in 1887 as Münchener Beobachter and renamed Völkischer Beobachter around 1918-19, it was sold to the Thule society in 1919 and then resold to the Nazi party in 1920. To boost the newspaper's size and frequency from weekly to daily, in 1923 Frau Gertrud von Seidlitz' donated 30,000 goldmarks and Ernst Hanfstaengl 1000 (d'Almeida [2006] 2008: 21) - a capital transferred from Finland and the United States respectively (Layton 1970: 357). It was banned after Hitler's failed coup in 1923 but resumed in 1925, having Max Amann as publisher and Dietrich Eckart as editor. Alfred Rosenberg succeeded Eckart in 1923-38, followed by Wilhelm Weiss through 1945.

In the party's hands, the logo changed to Roman letters in August 1923. A redesign in January-March 1930 added thick strokes underlining the headlines (often in slab serif) and introduced photographs. In itself, the newspaper was a miscellaneous of letterings but compared to the competitors the front page sounded like a parade of loud Fraktur letters on a somewhat modernist backdrop. Despite the centre-aligned titles, it contrasted other newspapers in a modernist-looking way, especially thanks to the headline's red underlines that seemingly plagiarized Tschichold's design in his edition of Typographische Mitteilungen published in 1925, thanks to typographic details in Paul Renner's Futura bold and due to the prominence of photographs (Figures 21-23). Tschichold was certainly aware of the redesign and not only because the Völkischer Beobachter was the leading newspaper of the Nazi party. On 22 March 
1930, it published a libel against Tschichold's appointment as a teacher at the Master school for Germany's printers in Munich on the grounds that he was considered a 'Bolshevist'. The article was used in 1933 to incriminate Paul Renner, who had hired him (Burke 2007: 138). Political prosecution notwithstanding, the Nazi propaganda was keen to use elements of Tschichold and Renner's typography.

Considering the practicalities of replacing newspaper typefaces at the time, the Völkischer Beobachter was quick in following the 1941 anti-Fraktur directive. Headlines changed to Roman on 18 March 1941. In June, the front cover no longer had Fraktur in the body text either, and in August, there was almost no Fraktur left. Rather than Roman old-style serif typefaces, headlines were set in Grotesks and slab serifs that further borrowed from modernist guidelines (Figure 24). Such style contrasted the Völkischer Beobachter's much written content, according to which the past surpassed the present, culturally at least: from Michelangelo to Shakespeare it claimed germaneness and even Nazi spirit in disparate authors (Dennis 2012: 11).

The Ahnenerbe followed a similar method but was much stricter in the fabrication of a great past of unmixed 'Aryan' blood and culture. Probably their differences reflected the ranks of 'Aryans' in the Nazi system, Ahnenerbe editions aspiring to an elite and Völkischer Beobachter targeting a broader audience.

Women were ranked lowly and addressed accordingly despite the Nazi claims to the contrary. Typographically, this meant for example the use of Grotesk for SS men and Sütterlin script for women and children: in most cases, the two styles were not displayed in the reverse order (Figures 25-27). Hitler's own typographic signature was already in mechanic-styled uppercase Grotesk in 1939 - thus before the Fraktur ban, after which Grotesks spread across the regime's typography. Hitler's letterhead, golden embossed, was in a Grotesk of modernist form but unmodernist colour (Figures 28-29).

During the 1936 Olympic games, international visitors also saw the regime in a modern-like style in the catalogue Amtlicher Führer durch die Ausstellung Deutschland, the official guide to the exhibition about Germany shown from 18 July to 16 August in Berlin. Designed with modernist signatures such as square format, photographs of geometric composition and twocolumn texts in Didone typestyle, and lacking the thick strokes of the Völkischer Beobachter, it looks like a ghostly ancestor of the functional typography that Max Bill's article would defend ten years later. Functional typography, he stated, simplified the earlier modernism, which is arguably, where the catalogue also arrived except for the illustration on the cover. As usual, Roman typefaces marked the text as international-oriented. Corporations such as Siemens, known for having exploited the slave labour from concentration camp victims (Hayes 1998), 
were promoted in full-page advertisements - Siemens' page is in a Grotesk style that modernism had been consolidating as symbol of industry and progress.

Bill and Tschichold were possibly unaware of this catalogue but Tschichold did hold in his personal collection a brochure about the same exhibition, also square-sized, designed by former Bauhaus alumni and teacher Herbert Bayer (MoMA n.d.). Bayer's design propagandized industrial power in full-page photomontages, a technique 'closely bound up' with the New Typography, in Tschichold's words (Burke 2007: 286).

Thus, nostalgic nationalism - 'Heimatstil' according to Bill - was but one layer of the Nazi image. Surely an important layer, and of popular resonance given the anti-modern sentiment across the German audience (Robertson 2001). But for this very reason a layer for national consumption, to represent the presumed shared ancestry of the Volk community. Meanwhile, a design vocabulary was borrowed from modernism to express male-only power, progress, order and new worldwide empire.

Thus, above the 'Aryan' racial community, addressed and portrayed in traditional stereotypes, stood the further supreme group of male leaders, the architects and administrators of mass-scale machines of murder. Fraktur functioned to speak to and about the national community which, though defined by its alleged racial supremacy, was inferior to the highest class of men - selfstyled in Grotesks - that planned and led the holocaust.

M. A. K. Halliday made the point that language shapes our perception of reality and, conversely, is shaped by how previous uses of language unfolded in time and in people's lives. 'What can be meant, at any moment in the discourse, is very much a product of history: of what could be meant, and what has been meant, before' (Halliday [1992] 2003: 360). Accordingly, Nazism found in Fraktur a pre-existing differentiator of 'foreign' and 'German' readers, which it thus manipulated for its unhampered definition of 'foreign'. This pre-existing convention facilitated the use of letterforms as labellers of race, religion, gender and different classes of 'Aryans'. Building on old usages, new meanings emerged.

Fraktur, Roman, italic and handwriting styles furnished the Nazi communication in what seems a random fashion, but oftentimes each style targeted a segmented audience. Some situations look designed with consistency considering who are the speaker and addressee, what is being told and how - roughly the tenor, field and mode of Systemic Functional Linguistics (Halliday [1992] 2003: 362). One such situation is state-promoted engine of murder, handwritten or typeset in Grotesks (Figures 30-31). Another situation is the blood and soil genre, expressed mainly in Fraktur and sometimes cursives (Figure 32). A situation designed in variable but 
conceptually consistent ways is the discourse for exclusion, where the excluded group has a lettering or typeface different from the one that predominates in the overall design (Figure 33).

However useful Fraktur was as a nationalist instrument, it did not have a fundamental 'Aryan' status nor was it particularly valued in the highest Nazi hierarchy, as Ahnenerbe editions suggest and its ban evidence. More valued was Wirth's 'philology' that traced the origin of the Roman alphabet back to a rune-styled 'Aryan' script from Atlantis. Or, the Codex Aesinas, handwritten in a Roman style and containing what was believed be a historical evidence of Nazi convictions.

The effect of Nazi propaganda is perhaps unmeasurable since the propaganda itself cannot be isolated from a context of genocide and the assured destruction of dissidents' lives. The allpervading violence surrounding the messages, which could not but have affected the audience's interpretation, was constitutive of that propaganda, as was the prolonged repetition of the same message over and over. Besides, typography was accompanied by images, texts and real-life policies meant to desensitize the 'Aryan' community and dehumanize those excluded from it.

But monumental violence was not yet fully available before the regime, and the Nazi party's rise to power bear witness of how appealing its image once was. Probably, there was public interest in how the party framed problems and solutions: it stated that Germany was originally a splendid racial community of women and man that did not deviate from their proper roles; the 'Aryan' community then declined after being contaminated by the outsiders, the Jews, the foreigners, and was about to perish because of such racial and gender disruptions. Then, the party presented itself as the only strong/male enough option to rescue those good old days. Paradoxically, but this was part of the appeal, it fashioned itself as new, modern, science-based, different. Within this binary old-new, women-man, 'Aryan'-Jew, national-foreign, Fraktur scripts served the old 'Aryan' motherland, while Grotesks (borrowed from modernism) helped shape the image of a new mechanical order.

\section{Nationalism and written language}

'From the start the nation was conceived in language, not in blood', wrote Benedict Anderson ([1983] 2006: 145) in Imagined Communities: Reflections on the Origin and Spread of Nationalism. This claim is at the core of Anderson's causal connection between the printing business and the emergence nationalism since the nation, he argued, not only was but it essentially is a community imagined through language, not through race. Because it is so imagined, the nation is rather open-ended in his account: "one could be "invited into" the imagined community. Thus today, even the most insular nations accept the principle of naturalization' (Anderson [1983] 2006: 145). German language is especially central in 
Anderson's lineage, which states that Luther's Bible standardized German and modelled the conversion of other vernaculars into print-languages, a precondition for national consciousness.

It is the very interplay of published written language and racism, religion, culture and nationalism that one sees across the lettering and typography of Ahnenerbe editions, NS-FrauenWarte, Völkischer Beobatcher and of Nazi ephemera. Far from neutral, letterforms represented such things as exclusion and gender stereotypes. In Imagined Communities the printed versions of vernacular languages - the 'print-languages' - are mainly a transparent content-sharing vessel (to transmit experiences, ideas, information) and to a great extent unaffected by speech genres or variations of script, though Anderson approached sacred languages in a different way.

But everyday language has intricate layers that potentially gather but also separate people. It includes and excludes. Under Nazi rule even the subtlest layers gained great importance as the regime sought to enter all spheres of people's lives. Thus, the Nuremberg laws that revoked the German citizenship of Jews and people of Jewish descent also prohibited them to use the national colours, symbolic and legal exclusion being inseparable.

The question that Imagined Communities seeks to answer - how did nationalism emerge? implicitly asks to what extent is the nation a self-evident methodological premise. The very Nazi nationalism seems somewhat international considering the influence upon it by, for example, Chamberlain, Darré and Wirth, born in England, Argentina and the Netherlands respectively, and that the Nazi-published propaganda had international support.

From a typographic standpoint, a fierce search for national letterforms before and during the Nazi regime arrived at unstable soils, such as rune-styled lettershapes from an imaginary sunk continent, or Fraktur typefaces that ended up banned as anti-German. But as Eric Hobsbawm ([1983] 1992: 1-14) claimed, national symbols have no need of fact-checked historical origin, their function is to construct a vivid image of the nation, whether or not out of sheer invention. To complicate things further, rune-styled letters had religious significance blended with scientific one for Wirth and Himmler's Ahnenerbe, which wielded science to legitimate previously held beliefs (Winter 2016: 25-27).

All examples discussed above were conceived to speak the Nazi voice, but when one looks outside them, it is striking how many letterings, typefaces and layout styles disappeared after Hitler took power. The difference between the design made in Germany before and during the regime eloquently says so and is documented for example across the book covers of S. Fischer Verlag (often designed by George Salter before 1934). To build a national image, the Nazis controlled the uses of letterforms to an extreme. The outcome shocks for everything that was removed from people's sight and for the repetitive stereotypes that such erasure gave way to. The 
typographic nationalism produced under Nazi rule, which revolved around a national-racial community of strict boundaries, implied unlimited extermination. So unlimited that even its strategic instrument for segregation - the Fraktur styles - also vanished.

It is worrisome to see what, in the end, remained as the typefaces that the regime not only authorized but indeed privileged: Hitler's directives given around five weeks before his suicide were recorded on the Reich's official letterhead and under stamps whose typographic style in Grotesks is now internationally commonplace, in fact it is common to the point of being unnoticeable and that up until these days still symbolizes neutrality, order and progress (Figure 34). Nazism does not necessarily announce itself in strident shapes, it can be cast in forms that camouflage as normality 


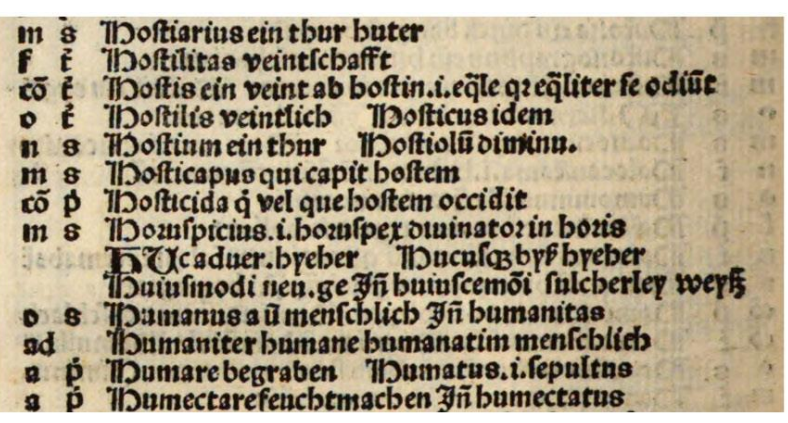

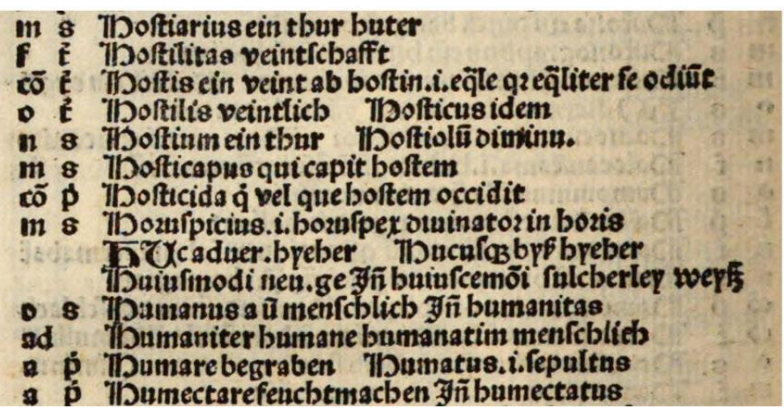

Germ.
Dutch. Kokarden.
Don. Kokarder.
Swed. Cocarder.
French. Cocardes.
Ital. Nappe, Fiocchi.
Span. Cucardas.
Port. Topes.
COCOA NUTS.
Gern. Kokosnüsse:
Dutch. Kolosnooten, Kalappus-
Don. Kooten, Klapnooten.
Swerd. Cocosnö̈dter.
Frenc. Cocos.
Ital. Cocchi.
Span.
Port. Cocos.
Russ. Kokos.

Ital. Olio di baccala o merluz span. Aceite de Merluza.
Port. Oleo de bacalhão.

COFFEE, COFFEE-BERRIES Germ. Koffe, Koffebohnen. Dan. Kaffe, Kaffebönner. Swed. Koffe. French.
Itsal. $\}$ Caffe. Ital. S Cafe.
Span. Cafe. Span. Cafe.
Port. Caffé. Russ. Kofé. Lat. Coffea, Caffea OIFs, CAPS. Germ. Haube Dutcb. Huiven, Kuiven.

Figure

\section{Det Dentitye Corteff} single copies a cents. Baltimare, Mto., Ginuftug, Den 27. Ilpril 1918.

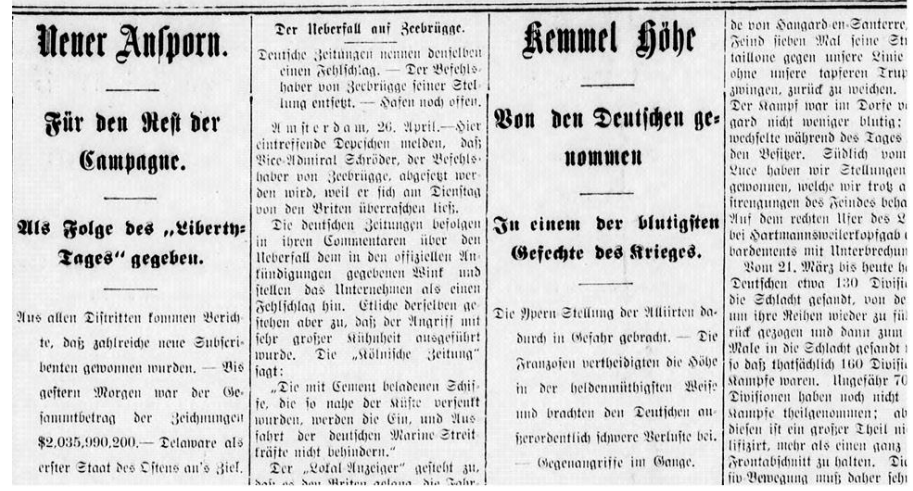

Figure 4

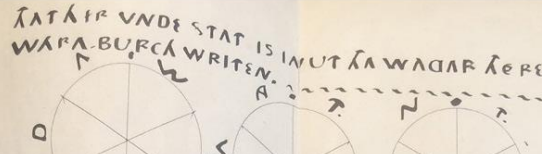

tatiol tatistit SENDTITÉkNA tón DA.S. AK KONTANAT KORMA SINNEBILD WRA TID KEM. FAT IS FIN ISfRA T. BIIIN WQRUT KAT IOL MOROAINERODER KER EVAMIK KATSTANOROMMEKLAPS. XANAAEK tRIA TEX TA tASTA TEX - KA tASTA EREMODER WERE KE KRTIU KATT RUN IF tKA KMPANDESKRIFE KON MAK ARG. AIR WITkGNIA. TATIS SEkGNIA OOD KREIAR. KENEALDA.KIRKGR ASVNDEROANA TEL NOMAR TONMAKAD KRR STANDAND RUNSKRITT BEDE. TISKGRVMBENAVTTODFO

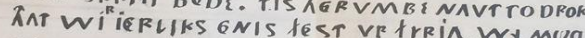
ON WRALOA EVO KANKTOWIA KAT hISIN CAST SAXSRDEINVR VSA E TLA KS T TARA lGTN. VNDER hI RATID KEK fINOA AKENSKR Itr UTtUNDEN. MEN KAT WERE SAKATtAR ANOR ANO tVL MIR trisLA ANDIROLUM FAt FA AfrerkUMANDA KGRot Kíu BITIVD NESE RIA VRLERENAAVE. AKEREI AAVON hiA VS SRRIfT LERED BINOMA KA XINNA. F̂ATriar ANDRA kREKA-LANDAR MENKIA NISTON NAVT CODKATET TON ST IOL MAKAD WAS ANDKATE XERVMBE ALTID S KREVEN YMAMAD

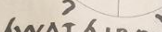

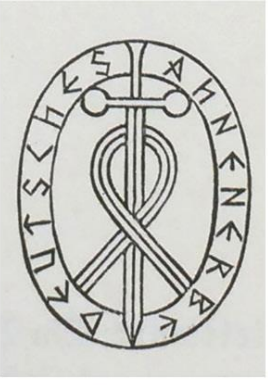

Figure 5

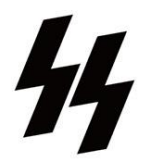

Figure 6

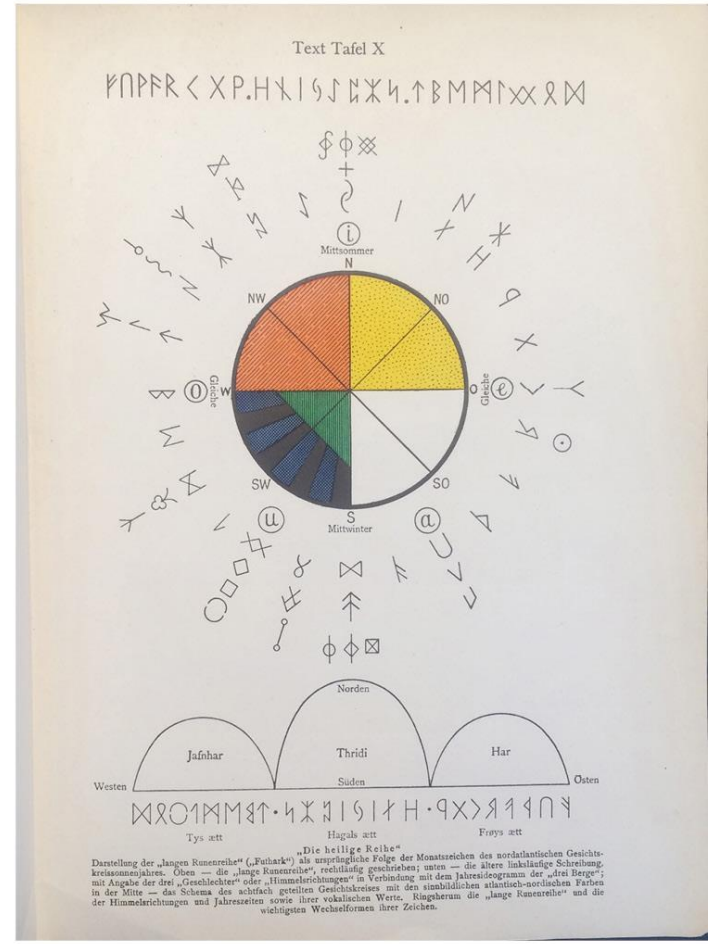

Figure 7
Hieroglyphe $\neq$, hat den Lautwert SIG der untergehenden Sonne). Auch dieser als $S I G-T y r$ (Ti-ur), für den sich senken. "Zwei Berge" im Westen eingeht: $И \uparrow \boldsymbol{B}$ ischen auch das Symbol für den Gott großen Wohnung", das ist der Totenensch, Mann" (semit. amêlu) und PA atlantisch-nordischen Schriftreihe. Den

Figure 9

ie, Sammlung 21uguft Bacbmann (5rimatmufeum)

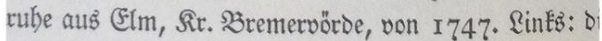
Darunter Das̉ Marfereuz $X$, oben und unten bie beibe it bem $\phi$ auf Dem $\sharp$ Deffen 2ifte Durch Monde $\because$ zeigt Die orei গ⿰冫欠urzeln A.

3, SISeftsr: Fingang Der Echloß̈tirche. Segenuberft ng mit bem breifproffigen Silienftengel $\Psi$, rechts bie $X$ beroorgeboben.

Rr. Şameln= Pytmont, Nir. 96: Tor von 1840 , T

Figure 10 


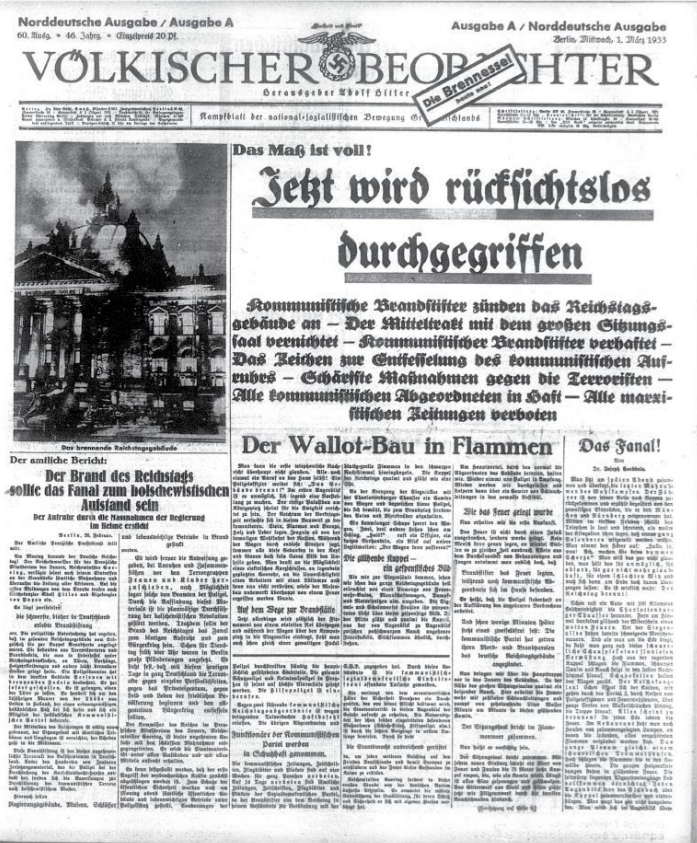

Figure 21

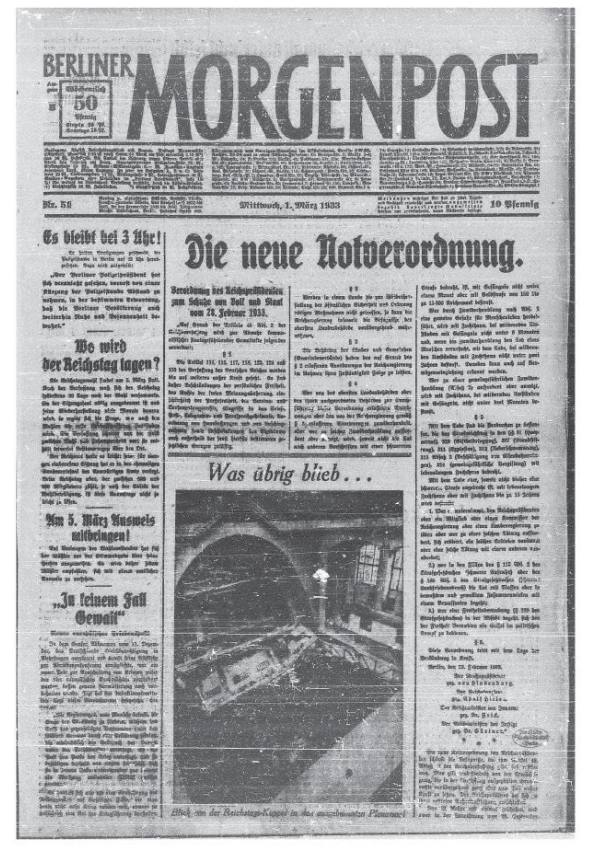

Figure 22

\section{tolkal-Anetimer}

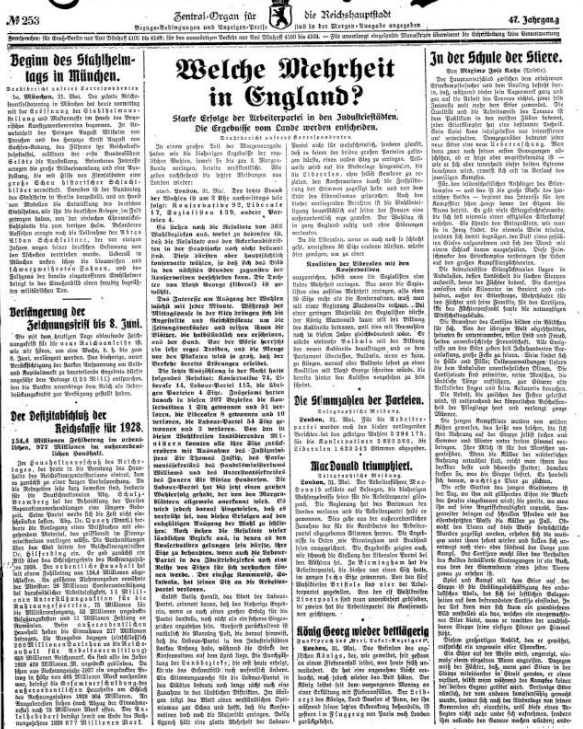

Heule beginn: Zwangsarbelter Austro-Marxist Kajelan Klug erzählt Wiener Ausgabe तind

VOLKISCHER BEOBACHTER

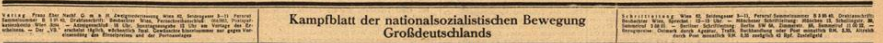

Sowjetverleidigung in der Westukruine vor dem Zusummenbruch

Die größte Sklaverei der Weltgeschichte!

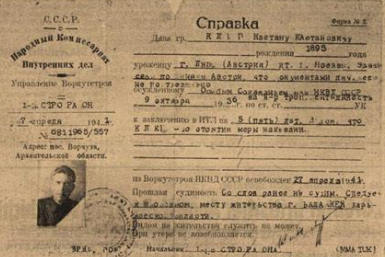

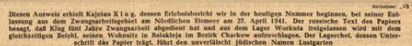

Erlebnishericht aus dem Struflager der GPU.

ox a sum
Odessa eingeschlossen Nikolajew umfaßt

Siegreiches Vorgehen der verbïndeten Truppen

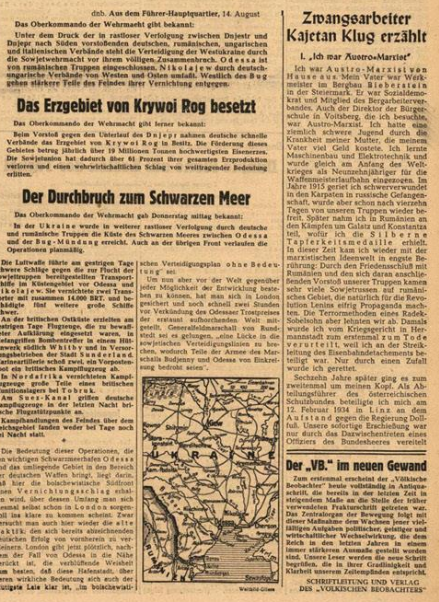

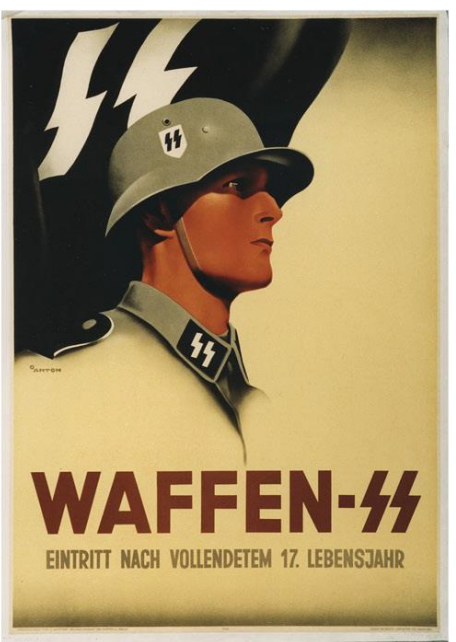

Figure 25

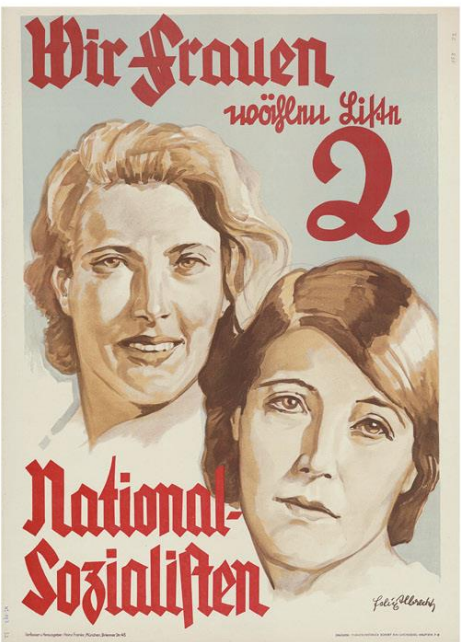

Figure 26
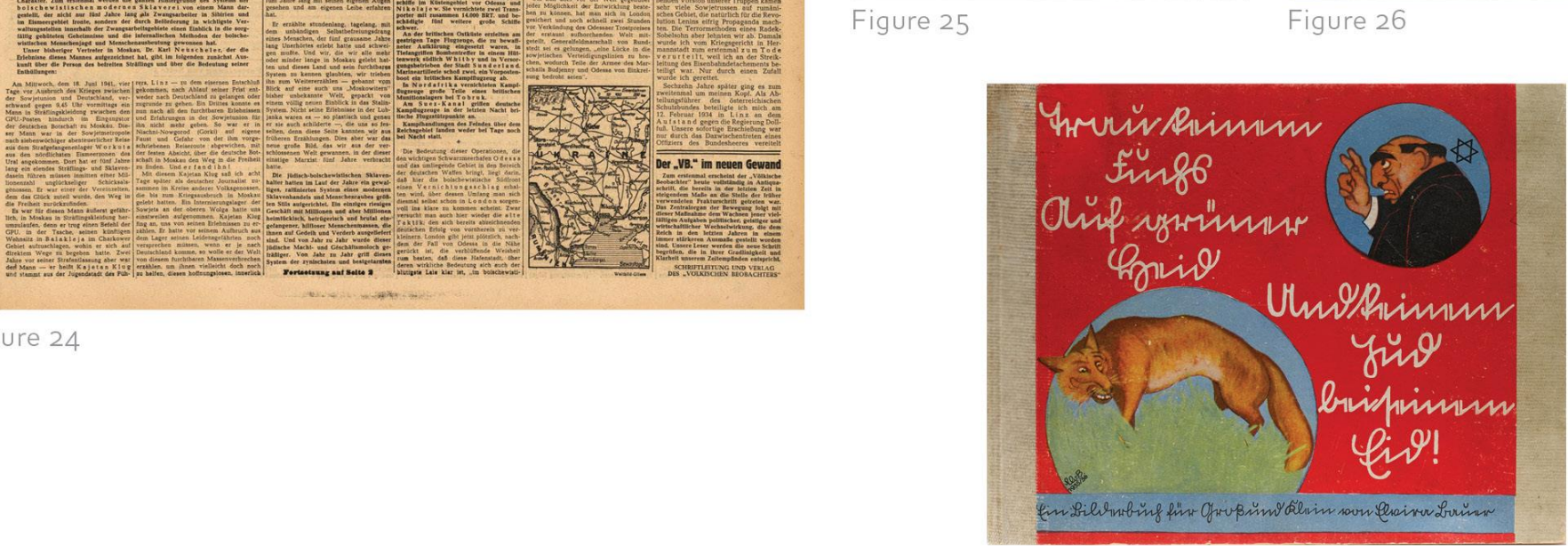


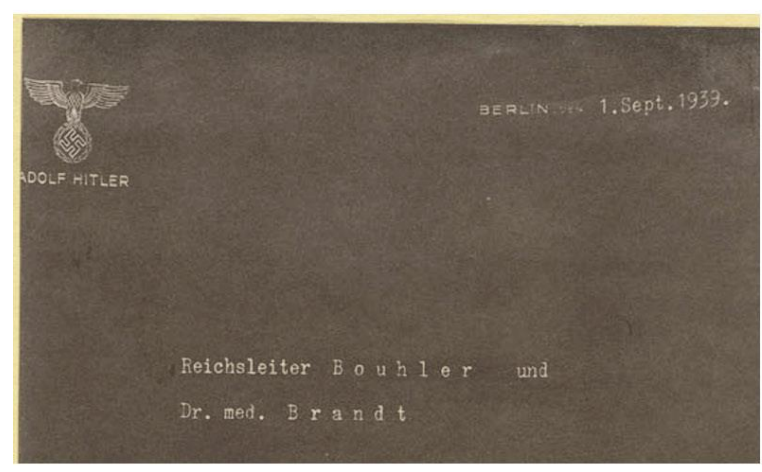

Figure 28

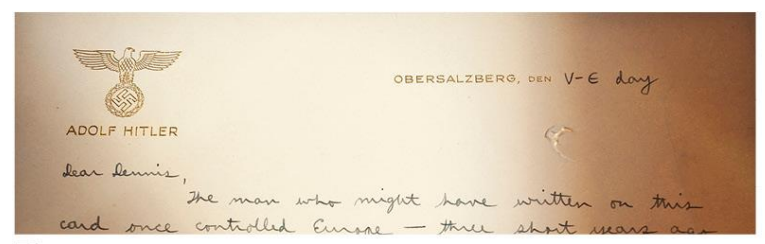

Figure 29

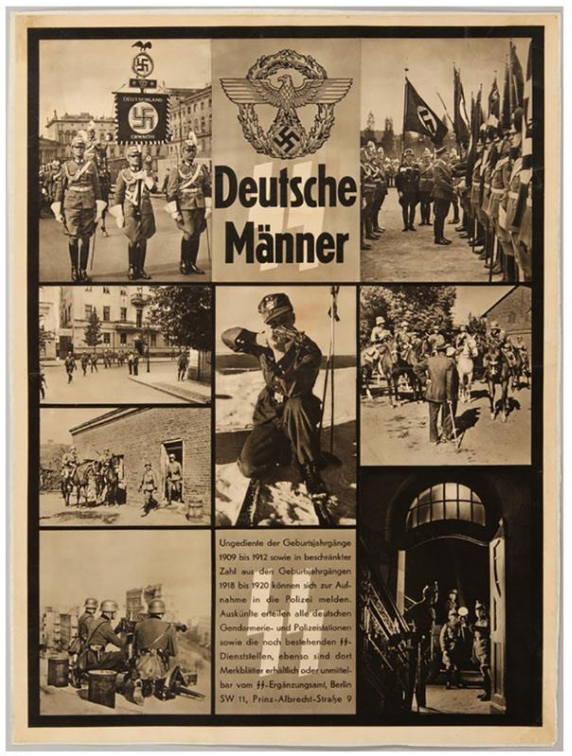

Figure 30

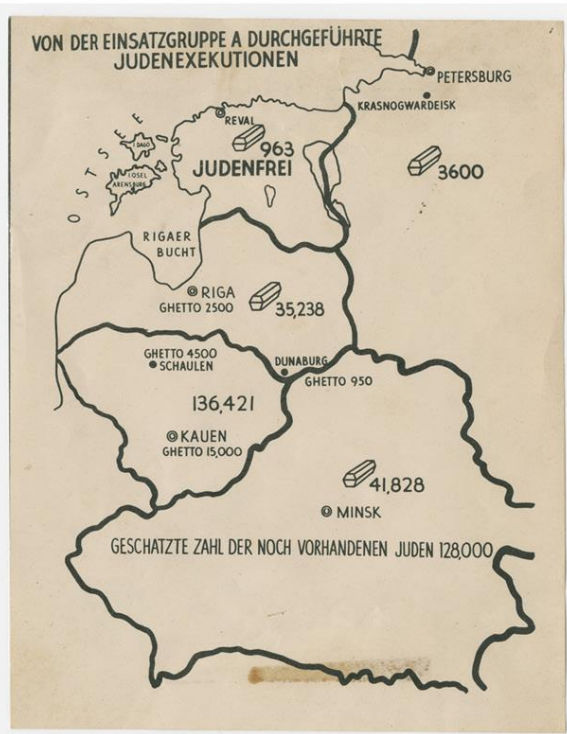

Figure 3

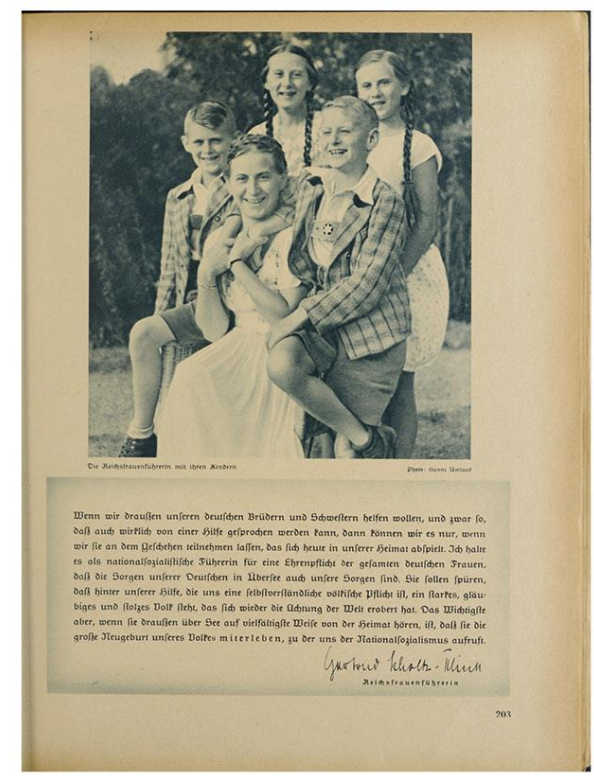

Figure 32

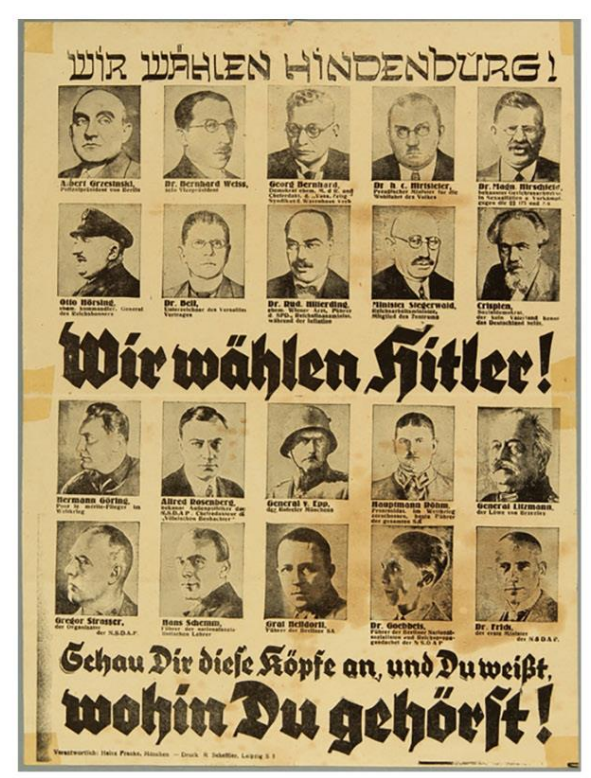

Figure 33

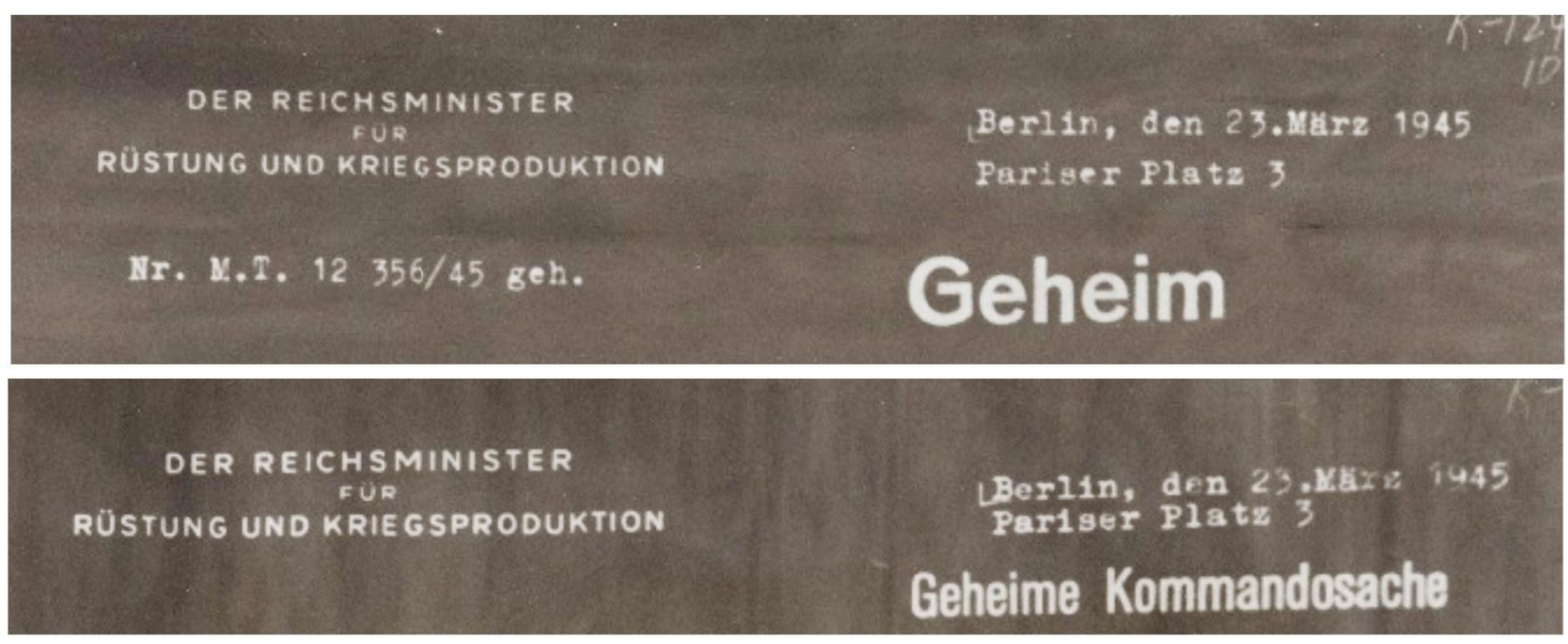

Figure 34 
Figure 1: Latin and German in Fraktur (Textura style) in the Latin-German dictionary Vocabularius optimus. Inside page (detail). Printed by Melchior Lotter. Leipzig. Original book size: $16.8 \times 24.4 \mathrm{~cm}$. Public domain. Source: British Library. Date: 1501.

Figure 2: Multilingual dictionary Thesaurus Polyglottus. Inside page (detail). Printed by Hieronymus Megiser. Frankfurt am Main. Original book size: $10 \times 16.5 \mathrm{~cm}$. Public domain. Source: British Library. Date: 1603 .

Figure 3: Universal European Dictionary of Merchandise in the English, German, Dutch, Danish, Swedish, French, Italian, Spanish, Portuguese, Russian, Polish and Latin languages. Inside page (detail). Printed for J. Johnson in St. Paul's Church Yard. I. Remanat in High Holburn, and W. Remanat in Hamburgh. Original book size: $22 \times 28 \mathrm{~cm}$. Public domain. Source: Wellcome Collection. Date: 1799.

Figure 4: Der Deutsche Correspondent. Front page (detail). Baltimore, MD. Public domain. Source: Library of Congress. Date: 27 April 1918.

Figure 5: Ahnenerbe imprint. From the book Germanische Gemeinschaftsformen, by Von Richard von Kienle. Published in Berlin, printed by Kohlham-mer in Stuttgart. Ahnenerbe edition. Original book size: $17 \times 24 \mathrm{~cm}$. Public domain. Source: British Library. Date: 1939.

Figure 6: Rune-styled insignia of the SS (Schutzstaffel).

Figure 7: Der Aufgang der Menschheit. Last page of inserted booklet (detail). Herman Wirth. The runic forms included within Wirth's text look like the lettering of the Ahnenerbe imprint and the SS insignia. Published by Eugen Diederichs Verlag. Jena. Original book size: $21 \times 28.5 \mathrm{~cm}$. Public domain. Eugen Diederichs Verlag. Source: British Library. Date: 1928 .

Figure 8: Thet Oera Linda Bok, Naar Eeen Handschrift uit de Dertiende Eeuw. 'Facsimile' of the fake 'manuscript of the 13 th century' in rune-styled letter attached to a spread. Leaf size: $18 \times 27$. Original book size: $12.5 \times 20 \mathrm{~cm}$. Public domain. Source: British Library. Date: 1872.

Figure 9: Der Aufgang der Menschheit. Inside page. Symbols inserted within the text (detail). Published by Eugen Diederichs Verlag. Jena. Size: $21 \times 28.5 \mathrm{~cm}$. Public domain. Source: British Library. Date: 1928 .

Figure 10: Urväter-Erbe in deutscher Volkskunst. Oskar von Zaborsky-Wahlstätten. Inside page. Symbols inserted within the text (detail). Published by the Ahnenerbe. Original book size: $21 \times 28.5 \mathrm{~cm}$. Public domain. Source: British Library. Date: 1936 .

Figure 11: Handschriftliche Untersuchungen zu Tacitus Agricola und Germania. Mit einer Photokopie des Codex Aesinas. Inside spread of the facsimile of Codex Aesinas, the fifteenth century manuscript copy of Tacitus' Germania. Published by the Ahnenerbe. Size: $21 \times 28.5 \mathrm{~cm}$. Public domain. Source: British Library. Date: 1943 .

Figure 12: Hand-lettered title and body text in Fraktur (Schwabacher style) in NS-Frauen-Warte. Inside page (detail). Year 13. Heft 2. Page 14. Size: $21.3 \times 24.3 \mathrm{~cm}$. Public domain. Source: Heidelberg University Library. Date: 1944.

Figure 13: Poster Ausmerzung des Kranken und Schwachen in der Natur (The eradication of the sick and weak in nature), from the racial science textbook Erblehre und Rassenkunde für die Grund- und Hauptschule (Heredity and Racial Science for Elementary and Secondary Schools), by Alfred Vogel. Munich. Public domain. Source: United States Holocaust Memorial Museum Collection. Date: 1938.

Figure 14: Schwachsinn verwandter Familien in vier Nachbarorten (Feeble-mindedness in related families in four neighboring towns). Erblehre und Rassenkunde, n. 27 (Heredity and Racial Science, number 27). Published by the Verlag für nationale Literatur (Publisher for National Literature). Stuttgart. Size: $29.21 \times 38.735 \mathrm{~cm}$. Public domain. Source: United States Holocaust Memorial Museum. Date: c. 1935.

Figure 15: Poster containing and illustrating the Law for the Protection of Blood and German Honor, one of the Nuremberg Laws. Fraktur is used within national borders (and towards the poster's reader), while signs in Grotesks address the bordering countries. Poster number 70 in the series Erblehre und Rassenkunde (Heredity and Racial Science). Stuttgart. Public domain. Source: United States Holocaust Memorial Museum, courtesy of Hans Pauli. Date: c. 1935.

Figure 16: NS-Frauen-Warte. Article about a home in Poland for German elderly people. Year 9, Heft 8. Page 115 (one of the front pages of this issue). Photo credit: Stewner. Public domain. Source: Elbląska Biblioteka Cyfrowa. Date: October 1940.

Figure 17: 'Blood and soil' cover of NS-Frauen-Warte, the second cover after the annexation of Austria. The first one was a map of the new German territory. Year 6. Heft 22. Public domain. Source: Elbląska Biblioteka Cyfrowa. Date: May 1938.

Figure 18: NS-Frauen-Warte. Article teaching how to build an outdoor fireplace. Inside page (detail). Year 13. Heft 1. Page 10. Public domain. Source: Heidelberg University Library. Date: 1944. 
Figure 19: NS-Frauen-Warte. Fashion story published in the back pages. It contrasts the countryside situation of Figures 16 and 32, published in the first part of the magazine. Year 11. Heft 7. Page 95. Public domain. Source: Heidelberg University Library. Date: 1942.

Figure 20: NS-Frauen-Warte. Article about foreign male workers. Inside page. Year 10. Heft 3. Page 38. Photo credit: Schwarting. Public domain. Source: Heidelberg University Library. Date: 1942.

Figure 21: Völkischer Beobachter. Front page of the edition after the Reichstag fire in 1933. Black and white reproduction. In the original edition, the thick strokes below the main headline are in red, like the subheadings in Jan Tshcichold's Typographische Mitteilungen published in 1925. The photographic message is clear and prominent on the top of the page. Typographic details at the top edge are in Paul Renner's Futura Bold. Public domain. Source: Zentral- und Landesbibliothek Berlin. Date: 1 March 1933.

Figure 22: Berliner Morgenpost, one of the German newspapers with the highest circulation in the Weimar Republic according to Bernhard Fulda (2009). Front page of the edition after the Reichstag fire in 1933 (black and white reproduction). Although in Grotesk-like lettering, this masthead is not as geometrical as a typical modernist typeface. Elsewhere, Fraktur predominates. The photograph is not as prominent and legible as the one published in the Völkischer Beobachter. Public domain. Source: Staatsbibliothek zu Berlin. Date: 1 March 1933.

Figure 23: Berliner Lokal-Anzeiger, one of the German newspapers with the highest circulation in the Weimar Republic according to Bernhard Fulda (2009). Front page (black and white reproduction). Fraktur was maintained until 1945 (the year it ceased publication). Public domain. Source: Staatsbibliothek zu Berlin. Date: 31 May 1929.

Figure 24: Völkischer Beobachter. Front page. Headlines are chiefly in sans-serif and include Futura on the top left. A text on the bottom right announces this issue as the first one completely in Roman typeface, though there is a headline in Fraktur style on the top right. Already in June 1941, the body text of the front pages had been changed to Roman. Public Figure 25: Waffen SS recruitment poster written in sans-serif. Illustration credit: Anton. Public domain. Source: United States Holocaust Memorial Museum. Date: 1941.

Figure 26: Election poster of the Nazi party targeting women, written in Fraktur and Sütterlin script (top right). Public domain. Source: United States Holocaust Memorial Museum. Date: 1932.

Figure 27: Cover of the antisemitic children's book Trau keinem Fuchs auf grüner Heid und keinem Jud auf seinem Eid (Trust no Fox on his Green Heath and No Jew on his Oath) written in Sütterlin script. Public domain. Source: United States Holocaust Memorial Museum. Date: 1936.

Figure 28: Hitler's name in uppercase Grotesk on his official letterhead. Order to Bouhler and Dr [Karl] Brandt to increase the authority of physicians to perform euthanasia (detail). Photostat reproduction. Public domain. Source: Harvard Law School Nuremberg Trials Project. Date: 1 September 1939.

Figure 29: Hitler's name in uppercase Grotesk, golden embossed on his official letterhead (detail). Letter by Richard Helms, Director of Central Intelligence/United States, to his son. Public domain. Source: CIA (Central Intelligence Agency). Date: 8 May 1945 (Victory in Europe Day).

Figure 30: SS recruitment poster entitled 'Deutsche Männer' (German Men). The rune-evoking SS insignia is inserted within the text, like in Herman Wirth's books. Public domain. Source: United States Holocaust Memorial Museum, courtesy of Galerie Prospect. Date: 1938.

Figure 31: Map showing the number of Jews killed by Einsatzgruppen A, one of the special SS and police units that mass murdered Jews, Roma and political opponents following the invasion of the Soviet Union in June 1941. This map was part of a report compiled by SS Brigadier General Franz Stahlecker (the Stahlecker Report). Public domain. Source: United States Holocaust Memorial Museum, courtesy of Thomas Wartenberg. Date: c. October 1941.

Figure 32: Portrait of Gertrud Scholtz-Klink and her children published on an inside page of NS-Frauen-Warte. She was head of the Nazi Women's Bureau and occupied the highest position assigned to a woman in the Nazi hierarchy. The 'blood and soil' style in this photograph is constructed from the combination of woodland in the background, natural light, the theme of a mother surrounded by many children as well as the hairstyle and clothes of Gertrud Scholtz-Klink and her daughters. The Fraktur typefaces of the body text and captions (here in Schwabacher style) were frequently used in 'blood and soil' contexts and as symbol of the 'Aryan' community throughout the Nazi propaganda. Photo credit: Hanni Umlaut. Year 3-4. Heft 7. Page 203 (one of the front pages of this issue). Public domain. Source: Heidelberg University Library. Date: $1935-36$.

Figure 33: Nazi Party poster of the 1932 presidential election campaign. Hitler's supporters are referred to in Fraktur while the support for Hindenburg is written in a pseudo-Hebrew lettering. The illustration of the Nuremberg Laws in Figure 15 is another example of discourse for stigmatization. In that case, the excluded group is addressed in sans-serif. Public domain. Source: United States Holocaust Memorial Museum Collection, Gift of the Katz Family. Date: 1932. 
Figure 34: Reich's letterhead and stamps in Grotesk typefaces. Pages 7 and 9 of a circular letter containing Hitler's orders and signed by Albert Speer, Minister for Armament and War Production (detail). Photostat reproduction. Public domain. Source: Harvard Law School Nuremberg Trials Project. Date: 23 Mar 1945.

\section{References}

Ahnenerbe (n.d.), 'Organizational chart and mission statement', Nuremberg Trials Project, https://nuremberg.law.harvard.edu/documents/1621-organizational-chart-and-mission?q=ahnenerbe\#p.1. Accessed 10 June 2019.

Alexander, Leo (1949), 'Medical science under dictatorship', The New England Journal of Medicine, 241:2, pp. 39-47.

Anderson, Benedict ([1983] 2006), Imagined Communities: Reflections on the Origin and Spread of Nationalism, London and New York, NY: Verso.

Bain, Peter and Shaw, Paul (1998), Blackletter: Type and National Identity, New York: Princeton Architectural Press.

Berner, Margit (2017), 'Nazi antropology and the taking of face masks', in P. Weindling (ed.), From Clinic to Concentration Camp: Reassessing Nazi Medical and Racial Research, 1933-1945, London: Routledge, pp. $121-37$.

Burke, Christopher (2007), Active Literature -Jan Tschichold and New Typography, London: Hyphen Press.

Childers, Thomas (1983), The Nazi Voter: The Social Foundations of Fascism in Germany, 1919-1933, Chapel Hill, NC: University of North Carolina Press.

d'Almeida, Fabrice ([2006] 2008), High Society in the Third Reich, Cambridge: Polity.

Dennis, David B. (2012), Inhumanities: Nazi Interpretations of Western Culture, Cambridge: Cambridge University Press.

Evans, David (2004), ‘The holiday of a lifetime', Eye , 53: Autumn 2004, http://www.eyemagazine.com/feature/article/theholiday-of-a-lifetime-text-in-full. Accessed 10 June 2019.

Fulda, Bernhard (2009), Press and Politics in the Weimar Republic, Oxford Scholarship Online, DOI: 10.1093/acprof:oso/9780199547784.001.0001. Accessed 10 June 2019.

Goebbels, Joseph (1933), 'German women’, Calvin University, 18 March, https://research.calvin.edu/german-propagandaarchive/goeb55.htm. Accessed 5 July 2019.

Gracia Alonso, Francisco (2008), 'Relations between Spanish Archaeologists and Nazi Germany (1939-1945): A preliminary examination of the influence of Das Ahnenerbe in Spain', Bulletin of the History of Archaeology, 18:1, pp. 4-24.

Halliday, Michael ([1992] 2003), 'The history of a sentence', in J. Webster (ed.), On Language and Linguistics: Vol. 3, New York: Continuum. pp. 355-374.

Harvey, Elizabeth (2003), Women and the Nazi East: Agents and Witnesses of Germanization, New Haven, CT: Yale University Press.

Hayes, Peter (1998), 'Profits and persecution: German big business and the Holocaust - J. B. and

Maurice C. Shapiro annual lecture', United States Holocaust Memorial Museum Center For Advanced Holocaust Studies, https://www.ushmm.org/m/pdfs/20050803-hayes.pdf. Accessed 5 July 2019.

Heim, Susanne (ed.) (2019), German Reich 1938-August 1939, vol. 2, Berlin: Walter de Gruyter.

Hertrampf, Susanne (2009), 'Gertrud Scholtz-Klink', Bundeszentrale für politische Bildung, 9 January, https://www.bpb.de/gesellschaft/gender/frauenbewegung/35323/gertrud-scholtz-klink?p=all. Accessed 6 June 2019.

HLSL (Harvard Law School Library) ([1946-47] 2016), 'Transcript for NMT 1: Medical case, HLSL Seq. No. 58 - 09 December 1946 Page 43', Nuremberg Trials Project, https://nuremberg.law.harvard.edu/transcripts/1-transcript-for-nmt1-medical-case/search?q=ahnenerbe. Accessed 4 July 2019. 
Hobsbawm, Eric ([1983] 1992), 'Introduction', in E. Hobsbawm and T. Ranger (eds), The Invention of Tradition, Cambridge: Cambridge University Press, pp. 1-14.

Horkheimer, Max and Adorno, Theodor ([1944] 2002), Dialectic of Enlightenment, Stanford, CA: Stanford University Press.

Junginger, Horst (2008), The Study of Religion under the Impact of Fascism, Leiden and Boston, MA: Brill.

Kämper-Jensen, Heidrun (1993), 'Spracharbeit im Dienst des NS-Staats 1933-1945', in H. Kämper-Jensen (ed.), Zeitschrift für germanistische Linguistik: deutsche Sprache in Gegenwart und Geschichte, Berlin: de Gruyter, pp. 150-83.

Kater, Michael H. ([1974] 2006), Das 4Ahnenerbe’ der SS 1935-1945: Ein Beitrag zur Kulturpolitik des Dritten Reiches, München: R. Oldenbourg Verlag.

Lang, Hans-Joachim (2013), 'August Hirt and "extraordinary opportunities for cadaver delivery" to anatomical institutes in National Socialism: A murderous change in paradigm', Annals of Anatomy-Anatomischer Anzeiger, 195:5, pp. 373-80.

Layton, Roland V. (1970), 'The “Völkischer Beobachter” 1920-1933: The Nazi Party Newspaper in the Weimar Era', Central European History, 3:4, pp. 353-82.

Lehmann-Haupt, Hellmut ([1954] 1973), Art under a Dictatorship, New York: Oregon Books.

Margolin, Victor (2015), World History of Design, vol. 2, London: Bloomsbury.

MoMA (n.d.), 'Deutschland Ausstellung, 18.Juli bis 16.August 1936', MoMA, https://www.moma.org/collection/works/7512. Accessed 6 June 2019.

Robertson, Ritchie (2001), The 'Jewish Question' in German Literature, 1749-1939 - Emancipation and Its Discontents, Oxford: Oxford University Press.

Rück, Peter (1993), 'Die Sprache der Schrift. Zur Geschichte des Frakturverbots von 1941', in J. Baurmann, H. Giinther and U. Knoop (eds), Homo scribens. Perspektiven der Schriftlichkeitsforschung, Tübingen: Niemeyer, pp. 231-72.

Rupp, Leila J. (1977), 'Mother of the "Volk": The image of women in Nazi ideology, Signs, 3:2, pp. 362-79.

Sneeringer, Julia (2002), Winning Women's Votes. Propaganda and Politics in Weimar Germany, Chapel Hill, NC: University of North Carolina Press.

Ulbricht, Justus H. (2004), “"Ein heimlich offener Bund für das große Morgen ...” Methoden systematischer Weltanschauungsproduktion während der Weimarer Republik', in H. Cancik and U. Puschner (eds), Antisemitismus, Paganismus, Völkische Religion / Anti-Semitism, Paganism, Voelkish Religion, München: K G Saur, pp. 65-82.

Ulrich, Herbert (2015), 'Forced labor', in P. Hayes (ed.), How Was It Possible?: A Holocaust Reader, Lincoln, NE and London: University of Nebraska Press, pp. 65-82.

Weiss, Natalie (2017), 'Parlamendarium Parlamentsgeschichte nach Kalendertagen', Deutscher Bundestag, bundestag.de. Accessed 8 August 2019.

Willberg, Hans Peter (1998), 'Fraktur and nationalism', in P. Bain and P. Shaw (eds), Blackletter: Type and National Identity, New York, NY: Princeton Architectural Press.

Winter, Franz (2016), 'Rewriting German and Japanese primeval history: A comparative historical analysis of the Takeuchi monjo and "Himmler's Bible", Religion, 46:1, pp. 7-31.

\section{Contributor details}


Mila Waldeck researches the intersection between design, discourse analysis and history with a focus on the politics and networks of different ways of publishing. She is former art director of the fashion magazine Vogue Brazil and is researching the dialogues between 1960s and 1970s conceptual art and design as a Ph.D. student in the Department of Typography and Graphic Communication at the University of Reading. Publications include a research on Beau Geste Press published in the Journal of Artists' Books, and an essay about the public sphere in a present-day art project, published in Situated Between. 